\title{
ORDERING PRODUCTION OF DOCUMENTS FROM ABROAD IN VIOLATION OF FOREIGN LAW
}

Should a court refrain from ordering the production of documents from abroad, solely because compliance with the order would necessitate a violation of the laws of a foreign nation? The courts have not fully analyzed the relevant issues presented by this problem and have reached inconsistent results. In order that a workable solution be achieved, it is submitted that the following vital questions must be answered: (1) Does a court have jurisdiction to issue such an order? (2) Under what circumstances should it do so? (3) Once an order has issued, what considerations should govern the imposition of sanctions for non-compliance?1

Courts have long been endowed with the power to order a party subject to their in personam jurisdiction to produce from abroad documents within the party's control. ${ }^{2}$ For a long time this power was also limited in

1 This comment is limited to an analysis of situations in which an American court has jurisdiction over the party ordered to produce. Problems of enforcement of American judgments abroad, or the enlistment of the aid of a foreign court to obtain testimony or documents by means of letters rogatory will not be treated. On these subjects, see Jones, International Judicial Assistance: Procedural Chaos and a Program for Reform, 62 YALE L.J. 515 (1953); Smit, International Aspects of Federal Civil Procedure, 61 CoLum. L. REv. 1031 (1961).

2 This situation most often arises in the case of a corporation having offices both in the United States and abroad. E.g., In re Nat'I Public Util. Investing Corp., 79 F.2d 302 (2d Cir. 1935); In re Ironclad Mfg. Co., 201 Fed. 66 (2d Cir. 1912); In re Grand Jury Subpoenas Duces Tecum, 72 F. Supp. 1013 (S.D.N.Y. 1947). If a party does not have control over the requested documents the order may not issue. Munroe v. United States, 216 Fed. 107 (1st Cir. 1914). See also Note, 62 YALE L.J. 1248 (1953). At one time this limitation on the courts' power was applied in all cases concerning banks as a consequence of the "separate entity" theory of branch banking, by which a bank was not considered to be in "control" of its branches. In re Harris, $27 \mathrm{~F}$. Supp. 480 (S.D.N.Y. 1939). See also United States v. Kyle, 21 F.R.D. 163 (E.D.N.Y. 1957); Chrzanowska v. Corn Exchange Bank, 173 App. Div. 285, 159 N.Y.S. 385 (1916) (branch bank not obliged to cash check drawn on another branch of same bank); Bluebird Undergarment Corp. v. Gomez, 139 Misc. 742, 249 N.Y.S. 319 (N.Y. City Ct. 1931) (attachment proceeding brought in New York was ineffective as against an account at the New York bank's branch in Puerto Rico); Richardson v. Richardson, [1927] P. 228 (judgment debtor's account cannot be garnished at main office of bank); Fordham, Branch Banks as Separate Entities, 31 Colum. L. REv. 975 (1931). However, the limitation of the Harris case has now been abandoned and banks with foreign branches are treated in the same manner as other corporations insofar as their obligation to produce documents is concerned. First Nat'l City Bank v. Internal Revenue Service, 271 F.2d 616 (2d Cir. 1959), cert. denied, 361 U.S. 948 (1960). But cf. United States v. First Nat'l City Bank, 321 F.2d 14 (2d Cir. 1963), aff'd en banc, 325 F.2d 1020 
accordance with the language of the first Restatement, Conflict of Laws: "A state can exercise jurisdiction through its courts to make a decree directing a party subject to the jurisdiction of the court to do an act in another state, provided such act is not contrary to the law of the state in which it is to be performed."3

This latter limitation, however, was rejected by the Supreme Court in Societe Internationale $v$. Rogers. ${ }^{4}$ This case was part of the complex Interhandel litigation in which the plaintiff, a Swiss holding company also known as I.G. Chémie, brought suit under the Trading with the Enemy Act for recovery of more than one hundred million dollars in assets seized by the United States during World War II. The Government challenged the claim, asserting that Interhandel, although incorporated in Switzerland, was an "enemy" within the meaning of the act (precluding an "enemy" from recovering seized assets) due to its intimate connection with I.G. Farbenindustrie, a German firm. At an early stage in the litigation, the Government moved for an order requiring the petitioner to make available for inspection and copying a large number of the banking records of Sturzenegger \& Cie. Not disputing the relevancy of these documents, Interhandel contended that it did not have "control" over them, as their production would violate Article 273 of the Swiss Penal Code (relating to "economic espionage") and Article 47 of the Swiss Bank Law (relating to secrecy of banking records). At the same time, the Swiss Federal Attorney, deeming that production of the accounts would violate Swiss law, confiscated them. This "confiscation" was essentially an order not to remove the documents. A Special Master found that there was no collusion between Interhandel and the Swiss government in the "confiscation," and that Interhandel had made good faith efforts to comply with the production order. The district court confirmed these findings, but nevertheless held that Interhandel had control over the documents, ordered their production, and, upon Interhandel's noncompliance, dismissed the complaint under Rule 37(b)(2) of the Federal Rules of Civil Procedure..$^{5}$

(2d Cir. 1964) (separate entity theory still valid as to funds transferred from New York bank to Uruguayan branch).

3 Restatement, Conflict of Laws § 94 (1934). (Emphasis added.) In SEC v. Minas de Artemisa, 150 F.2d 215 (9th Cir. 1945), the court, relying on this section, modified a subpoena requiring the production in Arizona of corporate books located in Mexico, since compliance would have required a violation of Mexican law. As modified, the subpoena ordered the corporation to apply to Mexican fiscal authorities for permission to remove the books, or, in the alternative, to require the corporation to allow the SEC to copy the books in Mexico, thus avoiding a violation of Mexican law.

4357 U.S. 197 (1958).

5 Societe Internationale Pour Participations Industrielles et Commerciales, S.A. v. McGranery, 111 F. Supp. 435 (D.D.C. 1953). 
On appeal, the Supreme Court affirmed the issuance of the discovery order. ${ }^{6}$ In so holding, the Court accepted the proposition that the district court had power to issue the order, and emphasized the courts' duty to carry out the policies of the United States as expressed by Congress:

In its broader scope, the problem before us requires consideration of the policies underlying the Trading with the Enemy Act....

In view of these considerations, to hold broadly that petitioner's failure to produce the Sturzenegger records because of fear of punishment under the laws of its sovereign precludes a court from finding that petitioner had "control" over them, and thereby from ordering their production, would undermine congressional policies made explicit in the 1941 amendments. ... Rule 34 is sufficiently flexible to be adapted to the exigencies of particular litigation. The propriety of the use to which it is put depends upon the circumstances of a given case, and we hold only that accommodation of the Rule in this instance to the policies underlying the Trading with the Enemy Act justified the action of the District Court in issuing this production order.7

The Court, however, reversed the dismissal of the complaint, holding that rule 37 should not be construed to authorize dismissal where noncompliance with the order was due to inability rather than willfulness or bad faith. ${ }^{8}$ The significance of this decision lies in the fact that the Court disregarded the strict territorial approach embodied in the first Restatement, Conflict of Laws. It should be noted, however, that the Court did not make clear under what circumstances production orders violating foreign law would be valid, when noncompliance with a production order would be sanctioned, and in what manner, nor whether a subpoena duces tecum could also be issued under similar circumstances.

In three recent cases involving subpoenas, the Second Circuit has not followed the lead of the Supreme Court. First Nat'l City Bank v. Internal Revenue Service, ${ }^{9}$ involved records, physically located at the bank's Panama branch, of a Panamanian corporation with offices both in Panama and New York City. The court refused to vacate the subpoena on the grounds that Panamanian law had not been adequately proven. In so holding, however, the court emphasized that had there been such proof, the subpoena would have been vacated.

6 Societe Internationale v. Rogers, 357 U.S. 197, 206 (1958).

7 Id. at 204-06.

$8 \mathrm{Id}$. at 212.

จ 271 F.2d 616 (2d Cir. 1959), cert. denied, 361 U.S. 948 (1960). 
Ings v. Ferguson 10 was one of the many cases resulting from the "financial chaos and ruin left by Lowell $M$. Birrell when that gentleman forsook these shores for those of our southern hemisphere neighbor, Brazil." 11 In a proceeding ancillary to a chapter $X$ reorganization in California, the New York district court ordered the New York agencies of certain Canadian banks to produce in New York records physically located in Canada. The subpoenas were quashed by the court of appeals as there was a possibility that compliance would have violated the laws of Quebec province. Letters rogatory were issued, since "whether removal of records from Canada is prohibited is a question of Canadian law and is best resolved by Ganadian courts." 12

The latest of these decisions, Application of the Chase Manhattan $B a n k,{ }^{13}$ approved the modification of a subpoena duces tecum directing the bank to produce records in possession of its Panama branch in violation of Panamanian law; the modified subpoena merely required the bank to cooperate with the Government in obtaining the records by application to Panamanian authorities. The court explained its decision in these terms:

The Government, as well as other litigants, has a real interest in civil and criminal cases in obtaining evidence wherever located. However, we also have an obligation to respect the laws of other sovereign states even though they may differ in economic and legal philosophy from our own. As we recently said in modifying subpoenas duces tecum in another case, "upon fundamental principles of international comity, our courts dedicated to the enforcement of our laws should not take such action as may cause a violation of the laws of a friendly neighbor or, at the least, an unnecessary circumvention of its procedures." Ings v. Ferguson. ... ${ }^{14}$

The tenor of this language is at variance with the Supreme Court's explicit holding in Societe Internationale. Moreover, the reasoning suffers from its broad reliance on "fundamental principles of international comity." The term "comity" has been used in so many senses ${ }^{15}$ that it

10282 F.2d 149 (2d Cir. 1960).

11 Ferguson v. Tabah, 288 F.2d 665, 667 (2d Cir. 1961).

12 Ings v. Ferguson, 282 F.2d 149, $152^{\circ}$ (2d Cir. 1960). The lower court had already quashed in part subpoenas duces tecum directing the New York agencies of certain foreign banks to produce documents from Cuba upon evidence that compliance would have subjected the banks' employees in Cuba to criminal penalties. In re Equitable Plan Co., 185 F. Supp. 57 (S.D.N.Y. 1960).

13297 F.2d 611 (2d Cir. 1962).

14 Id. at 613. (Emphasis added.)

15 The origin of the doctrine may be attributed to Ulrich Huber (1636-1694) of the 
can hardly be considered a very firm principle upon which to base judicial decisions. At least three interpretations can be found in the writings of courts and theorists: (1) That comity is merely an expression of politeness or courtesy on the part of the nation recognizing the foreign law; ${ }^{16}$ (2) that by comity the foreign law becomes a part of the legal system of the nation applying it; ${ }^{17}$ or (3) that comity is really a sort of reciprocal recognition by friendly nations of one another's laws. ${ }^{18}$ The last of these alternatives represents the traditional American view, and was early expressed by Mr. Justice Story, whose conception of reciprocity was based not only on convenience and utility, but also on the moralistic precept "do unto others as you would have done unto you." 19

Dutch School, who employed it to "modify and temper the vigorous application of territorial law and to accord recognition to foreign law on local territory." KunN, Comparattve Commentaries on Private International Law 29 (1937). In De ConFLICTU LEGUM, Huber laid down the three maxims which came to be the basis of the American doctrine of conflict of laws. Davies, The Influence of Huber's De Conflictu Legum on English Private International Law, 18 BRrr. YB. INT'L L. 49 (1937); See Lorenzen, Huber's De Conflictu Legum, 13 ILL. L. REv. 372 (1919). For a collection of some of the many attempts to define "comity," see Hanzard, U.S. Antitrust Process Beyond our Borders: Jurisdiction and Comity, NEw YORK BAR Ass'N, SECTION ON ANTTRUST LAw, SyMPosium 44, 47-50 (1953).

16 This has been the position generally taken by the continental jurists. Davies, supra note 15 , at 57 .

17 Livermore, the first American writer on the subject, seems to have taken this view in Dissertations on the Questions Which Arise From the Contrariety of the Positive Laws of Different States and Nations (1828). See Kuhn, op. cit. supra note 15, at 30. A later American theorist explicitly adopted this position, saying: "If we understand by 'comity' simply politeness, meted out either at the caprice of the judge, or granted in consideration of similar concessions by the state whose law is for the particular case accepted, then 'comity' is not the true foundation on which our acceptance of the rules of private international law rests. For when a foreign law binds a particular case, then it becomes part of our common law, and the parties are entitled of right to have it applied." Wharton, Conflict of Laws $\S 1$, at 6 (3d ed. 1905).

18 See Story, Conflict of Laws § 35, at 34 (1st ed. 1834).

19 In his treatise on the conflict of laws, Story expressed his view in the following manner: "It has been thought by some jurists, that the term, 'comity,' is not sufficiently expressive of the obligation of nations to give effect to foreign laws, when they are not prejudicial to their own rights and interests. And it has been suggested, that the doctrine rests on a deeper foundation; that it is not so much a matter of comity as of paramount moral duty. . . . The true foundation, on which the administration of international law must rest, is, that the rules, which are to govern, are those, which arise from mutual interest and utility, from a sense of the inconveniences, which would result from a contrary doctrine, and from a sort of moral necessity to do justice, in order that justice may be done to us in return. . . Id $I$. at $\$ \$ 33,35$, at 34. In Hilton v. Guyot, 159 U.S. 113 (1895), the Supreme Court held that comity did not require an American court to give conclusive effect to a French judgment for want of reciprocity on the part of France. The Court stated: "In holding such a judgment, for want of reciprocity, not to be conclusive evidence of the merits of the claim, we do not proceed upon any theory of retaliation upon one person by reason of injustice 
In addition to these definitional problems which were bypassed by the Second Circuit, it does not appear that any available interpretation justifies the generalization that the "fundamental principles of international comity" do preclude our courts from taking an action that may cause the violation of the laws of a foreign country. ${ }^{20}$

It is submitted that any discussion which proceeds from "comity" fails to grapple with the competing policies which arise when a court is asked to order the production of protected documents. On the one hand, the forum state has a strong interest in basing its judgment on all relevant information. On the other, it has an interest in not forcing the violation of foreign law. "Comity" recognizes only the latter interest, and then only from the point of view of proper interstate relations. But the domestic interest in full disclosure of facts in litigation is equally relevant and must not be disregarded. Recent authority has recognized this tension and the inadequacies of prior mechanical rules. The Restatement (Second), Conflict of Laws has replaced its original rule with a pronouncement significant in its omission of any restrictive clause or any reference to the laws of another state: "A state can order a person, who is subject to its judicial jurisdiction, to do an act in another state."21 The proposed

done to another; but upon the broad ground that international law is founded upon mutuality and reciprocity, and that by the principles of international law recognized in most civilized nations, and by the comity of our own country, which it is our judicial duty to know and to declare, the judgment is not entitled to be considered conclusive." Id. at 228. The New York Court of Appeals, in Russian Socialist Federated Soviet Republic v. Cibrario, 235 N.X. 255, 258, 139 N.E. 259, 260 (1923), stated in a similar vein: "Comity may be defined as that reciprocal courtesy which one member of the family of nations owes to the others. ... We do justice that justice may be done in return." But cf., Direction der Disconto-Gesellschaft v. United States Steel Corp., 300 Fed. 741, 747 (S.D.N.Y. 1924) (L. Hand, J.) (doctrine of reciprocity confined to foreign judgments).

20 "Comity persuades; but it does not command." Mast, Foos \& Co. v. Stover Mfg. Co., 177 U.S. 485, 488 (1900).

21 Restatement (Second), Conflict of Laws \& 94 (Tent. Draft No. 4, 1957). Note, however, comment (c) to this section: "Only in a most extreme situation, will a person be ordered to do an act in a state which is contrary to that state's criminal law. Such an order would not be conducive to the maintenance of harmonious relations between the states involved. It would also be unfair to the defendant, since it would place him in the dilemma of either obeying the order and thus rendering himself liable to punishment at the hands of the state where the act was done or else of subjecting himself, through disobedience of the order, to the risk of being held guilty of contempt by the original court.

"A court will also be extremely reluctant to order the defendant to do.an act in a state which might subject him to civil liability under that state's law. This is particularly true in a situation where it is likely that the defendant would be enjoined by a court of the second state from doing the act which he had been ordered to do by the forum. In such a case, the defendant could not obey one court's order without subjecting himself to the risk of being held guilty of contempt by the other." This caveat emphasizes the hesitance of the drafters to depart from the 
official draft of the Restatement of Foreign Relations is more explicit: "A state having jurisdiction to prescribe or to enforce rules of law is not precluded from exercising such jurisdiction solely by the fact that exercise requires a person to engage in conduct subjecting him to liability under the law of another state having jurisdiction with respect to that conduct."22

It should be mentioned at this point that laws inhibiting the removal of documents or the disclosure of their contents vary greatly. Some are purely technical or procedural, requiring that books and documents be kept at certain places (generally to be available for inspection by fiscal authorities). ${ }^{23}$ Waiver of these statutes should not be too difficult to obtain. Other laws (statutory and administrative) specifically prohibit the removal or copying of business books or documents pursuant to a foreign judicial or executive order; the sanctions provided may vary from a small fine to imprisonment. ${ }^{24}$ These laws are in part a manifestation of foreign misunderstanding and even distrust of American discovery procedures and antitrust policies, in part, a means of encouraging foreign investment which seeks the advantages of such laws and, in part, a reaction to what

traditional rule. Compare the approach of the Restatement, The Foreign Rerations LAW OF The UNITED States, \& 39 (Proposed Official Draft, 1962).

22 Restatement, The Foreign Rerattons Law of the United States § 39 (Proposed Official Draft, 1962). Comment (c) to this section is as follows: "Except in situations in which the rule stated in $\S 40$ [see note 31 infra] applies, the nature of the sanctions by which the rules of the respective states are enforced does not affect applicability of the rule stated in this Section. The rule applies in situations of criminal and civil liability, for violation of statute or breach of contract and also when the sanction takes the form of enforcement of a specific court decree or administrative order."

23 E.g., Panama: Art. 93 of Law No. 17 [1961] provides that business documents must be kept at a merchant's establishment and cannot be removed from the country. The maximum fine for a violation is 100 Balboas (approx. \$100). Quoted in Application of The Chase Manhattan Bank, 297 F.2d 611, 612 (2d Cir. 1962).

Mexico: Art. 65, Ley General del Timbre (Stamp Act) provides that account books must be kept in the taxpayer's office, unless in the possession of judicial or fiscal authorities. Art. 228 (xv), Codigo Fiscal de la Federación provides that failure to keep books or other documents required by the law in the places specified in the fiscal laws constitutes an offense punishable by fine. Quoted in SEC v. Minas de Artemisa, 150 F.2d 215, 218 n.8 (9th Cir. 1945). If a waiver cannot be obtained, it is generally possible to have copies of the documents made, or to allow inspection at the foreign situs without incurring a violation of the law. But see Art. 89 of Law No. 17 [1961] (Panama), infra note 24.

24 E.g., The Business Records Protection Act, Ontario Rev. Stat. ch. 44 (1950), provides that no person shall in compliance with the order of a foreign authority take or send or cause to be removed from Ontario any business or corporate documents. A violation may be punished with up to one year's imprisonment.

Art. 89 of Law No. 17 [1961] (Panama) provides for a fine of up to 100 Balboas as punishment for anyone who allows reproductions to be made of business documents for use in an action abroad in compliance with the order of foreign authority. Quoted in Application of The Chase Manhattan Bank, 297 F.2d 611, 612 (2d Cir. 1962). 
is considered an intrusion upon the sovereignty of the nation involved. ${ }^{25}$ Finally, there are the laws relating to the disclosure of banking or other business secrets, motivated by similar concerns, the violation of which may lead to both civil liability and the criminal sanctions of fine and imprisonment. ${ }^{26}$

Once it is recognized that "there is no jurisdictional limitation, strictly speaking, that the defendant should not be ordered to do an act in a state which is contrary to that state's law," 27 and that any limitation on the power of the court to issue such an order "is more in the nature of a self-imposed, than a jurisdictional limitation," 28 it becomes clear that it is unnecessary to be bound by an arbitrary rule when another course of action is more likely to lead to a just resolution of a controversy. ${ }^{29}$

25 E.g., the reaction of the governments of the United Kingdom, France, the Netherlands and Belgium, where the respective governments informed the companies involved that compliance with subpoenas duces tecum issued in connection with the international oil grand jury investigation, would violate the laws of their respective countries. See In re Investigation of World Arrangements with Relation to the Production, Transportation, Refining \& Distribution of Petroleum, 13 F.R.D. 280 (D.D.C. 1952). See also Economic Competition Law Art. 30 (Netherlands) [1956]: "Except in cases where an exemption or, upon request, a release has been granted by Our Ministers, it shall be prohibited wilfully to observe within Dutch Territory measures or decisions of another State which concern regulations on competition, positions on economic power or economic competition practices." Cf. Gill, Problems of Foreign Discovery, in Brewster, ANTtTRust and American Business ABroad 474, 482-83 (1958). For an example of foreign objections to American discovery methods, see Radio Corp. of America v. Rauland Corp., [1956] 1 Q.B. 618.

26 E.g., Art. 47 of the Swiss Banking Code provides for a punishment of up to 20,000 Swiss francs and/or up to six month's imprisonment, for anyone who "violates the duty of absolute silence with respect to a professional secret. . . ." Art. 273 of the Swiss Criminal Code provides for imprisonment as a punishment to anyone who makes trade secrets accessible to foreign governments or private entities. The judicial definition of "trade secret" is "any fact which the person in possession of it considers worth keeping secret. The unauthorized transmission of information about bank accounts to a foreign authority clearly constitutes this offense." Friedrich, The Anonymous Bank Account in Switzerland, 79 BANKING L.J. 961, 963-64 (1962). Furthermore, the violation of any person's right to the secrecy of his economic affairs, is an actionable tort under Art. 28 of the Swiss Civil Code and Articles 41 and 49 of the Swiss Code of Obligations. These articles provide for money damages and other reparations. Meyer, The Banking Secret and Economic Espionage in Switzerland, 23 GEO. WASH. L. REv. 284, 288 (1955); cf. Record, vol. 1, pp. 405-12, Societe Internationale v. Rogers, 357 U.S. 197 (1958). The law of Panama was recently changed to provide for coded bank accounts and the secrecy of bank accounts. Law No. 18 of Jan. 28, 1959.

27 Reporter's Note to § 94, Restatement (Second), Conflict of LAws, op. cit. supra note 21 , at 9.

28 Ibid.

29 Two recent articles, Note, Limitations on the Federal Judicial Power to Compel Acts Violating Foreign Law, 63 CoLUM. L. REv. 1441 (1963), and Note, Subpoena of Documents Located in Foreign Jurisdiction Where Law of Situs Prohibits Removal, 37 N.Y.U.L. REV. 295 (1962), assume, without discussion, that a party may be compelled to violate a foreign law. While this is the position taken here, it should be recognized 
The fault inherent in the mechanical application of an inflexible rule to the question of production is that such a rule can rarely achieve optimum results without working undue hardship on some parties. If the rule is that the documents must be produced under all, or alternatively, under no circumstances, in the one case, some parties will be placed in jeopardy for little reason; in the other, some parties who might easily have complied will not need to do so. Rather, the rule adopted should be the one most likely to place before the court all the relevant documents which can be produced without undue hardship to any party. Thus what is required is a rule balancing the interest in not ordering the violation of the laws of a friendly sovereign against the interest in obtaining certain information. ${ }^{30}$ Admittedly it is not easy to administer a rule founded upon a balancing of conflicting interests, but a court could readily do so upon making the following determinations:

(1) As to the necessity of the requested documents or information to the achievement of just results;

(2) As to the effect of the issuance or nonissuance of the proposed order upon the fulfillment of national policy objectives;

(3) As to the possible consequences faced by the party complying with the order (including the possibility of waiver by the foreign authority of enforcement of the law); and

(4) As to the availability and effectiveness of alternative procedures whereby the desired information could be obtained. ${ }^{31}$

that current opinion on the problem is hardly uniform. See 39 A.L.I. Procendincs 347-63 (1962) (consideration of RESTATEMENT, THE FOREIGN RELATIONS LAW OF THE UnIted States \$\$ 39, 40 (Proposed Official Draft, 1962)); 34 A.L.I. Proceedings 359-68 (1957) (consideration of Restatement (SECOND), Conflict of LAws $\$ 94$ (Tent. Draft No. 4, 1957)). See also In re Von Kantzow's Patent, [1944] Ch. 318; and the Prize Cases: The Kronprinzessin Victoria, [1919] A.C. 261; The Baron Stjernblad, [1918] A.C. 173; The Consul Corfitzon, [1917] A.C. 550.

30 A rule based on similar considerations has been evolved to govern the determination of the admissibility of privileged communications when the forum does not recognize the privilege being asserted. In such a case, especially when the forum's substantive Iaw governs, the privilege is generally not recognized. This result is reached since the forum has a strong interest in obtaining answers to questions of fact, and has no interest in fostering the type of confidential communications encouraged by the jurisdictions advocating the privilege in question. See 8 WIGMore, Evidence $\S \S 2285,2291$ (McNaughton rev. 1961); Restatement, Conflict of LAws § 597 (1934); Weinstein, Recognition in the United States of the Privileges of Another Jurisdiction, 36 Colum. L. REv. 535 (1956).

31 Restatement, The foreign Relations Law of the United States, op. cit. supra note 22 , at $\S 40$, offers a balancing of interest test: "Where two states have jurisdiction to prescribe and enforce rules of law and the rules they prescribe require inconsistent conduct upon the part of a person, each state is required by international law to consider, in good faith, the possible moderation of the exercise of its own enforcement jurisdiction, in the light of such factors as: (a) vital national interests of the states, 
The relevance of the first consideration is hardly disputable. It would serve no discernible purpose to order violation of the laws of a friendly nation in order to obtain unneeded information. ${ }^{32}$ The second consideration involves examination of the policies underlying the legal questions being litigated. For example, in Societe Internationale, examination of the policies underlying the Trading with the Enemy Act was crucial to the Court's approval of the issuance of the discovery order. ${ }^{33}$ This examination is necessary because courts react to the same problem in different ways depending upon the context in which the problem is presented. The realization of some policies is considered by the courts to be more important than the fulfillment of others. There, perhaps, lies the most reasonable explanation for the varying results reached by the Second Circuit. Although in First Nat'l City Bank ${ }^{34}$ the reason given by the court for not vacating the subpoena was that foreign law had not adequately been proved, the litigation involved income tax evasion, and perhaps the court was willing to go to greater lengths to enforce the income tax laws, than it was in Ings v. Ferguson ${ }^{35}$ to obtain documents in a proceeding ancillary to a chapter $\mathrm{X}$ reorganization. This variance is emphasized by the wholly different attitudes taken by the court in the two decisions. Whereas in First Nat'l City Bank the court expressed dissatisfaction with the thought that foreign law should cause the subpoena to be vacated, ${ }^{36}$ in Ings the court was willing to vacate the subpoena merely on a showing that compliance "may cause a violation of the laws of a friendly neigh-

respectively; (b) the extent and the nature of the hardship that inconsistent enforcement actions would impose upon the person; (c) the nationality of the person; and (d) the extent to which the enforcement action of either state can reasonably be expected to achieve compliance with the rule prescribed by that state." These criteria cannot adequately guide a court's determination of the problem presented. First, it is not the function of a court to make determinations as to the national interests of foreign nations; see text accompanying note 52 infra. Second, the nationality of the party subject to the order does not seem to be a relevant consideration; indeed, a rule giving preferential treatment to foreign corporations in the courts of the United States would hardly seem desirable. Third, the power of a court to enforce its orders is as irrelevant a consideration here as in other cases where potentially unenforceable judgments are entered.

32 In Societe Internationale the records in question might have had "a vital influence on this litigation insofar as they shed light upon petitioner's confused background." 357 U.S. at 205. The approval by the Supreme Court of the issuance of the discovery order in this case was probably due in no small measure to this consideration.

33357 U.S. at 204-06; see text accompanying note 7 supra.

34 First Nat'l City Bank v. Internal Revenue Service, 271 F.2d 616 (2d Cir. 1959), cert. denied, 361 U.S. 948 (1960); see text accompanying note 9 supra.

35282 F.2d 149 (2d Cir. 1960); see text accompanying notes 10-12 supra.

36 "If the Bank cannot, as it were, serve two masters and comply with the lawful requirements both of the United States and of Panama, perhaps it should surrender to one sovereign or the other the privileges received therefrom." $271 \mathrm{~F} .2 \mathrm{~d}$ at 620 . 
bor. . . ."37 If such considerations were instrumental in the outcome of those cases, the court should have enunciated them, and the principle emerging would be the supremely rational one that a court is and should be more willing to issue an order to produce if the national policy objectives are vital than if they are not..$^{38}$ Finally, the lack of national policy considerations might also go far toward justifying entirely different results when litigation involves only private parties disputing a private matter.

Consideration of the consequences to be faced by the party complying with the order is a natural duty of the court. If no consequences to the party were to ensue from compliance, there would be no reason for the court to refuse to issue the order; thus it is essential that the court explore the possibilities that the party may obtain a waiver by the foreign government of enforcement of the foreign law. ${ }^{30}$ If a waiver is not forthcoming, it is self-evident that a court will be much more reluctant to order a party to commit an act which might subject him to severe criminal liability than if the potential liability is merely the payment of a small fine.

As a final consideration, the court should investigate the availability of alternative procedures whereby the desired information may effectively be obtained. If an effective alternative exists, the court should consider action along the alternative line, as it is always preferable to pursue the lines of conduct least likely to offend friendly sovereigns. Generally these alternative procedures involve the issuance of letters rogatory or the taking of depositions. ${ }^{40}$ But sometimes more informal procedures are suggested, such as appointment of an independent investigator to examine the documents ordered produced. ${ }^{41}$ Although the use of these alternatives

37282 F.2d at 152. (Emphasis added.)

38 It has been urged that the policies underlying the Sherman Act, that is, the reconciliation of competition and cooperation, require overriding the policies of foreign nations against removal or disclosure of documents, whenever production of documents involves an antitrust action. Emmerglich, Antitrust Jurisdiction and the Production of Documents Located Abroad, 11 ReCORD of N.Y.C.B.A. 122, 131-34 (1956).

39 This procedure was utilized in United States v. Standard Oil Co., 23 F.R.D. 1, 4 (S.D.N.Y. 1958), where the court ordered defendants to attempt to obtain waivers of foreign restrictions on removal of documents, and provided that if these efforts failed, the good faith of the defendant's attempts would be adjudicated in an appropriate hearing.

40 See the comprehensive treatment of the problems arising from the use of these procedures in Jones, International Judicial Assistance: Procedural Chaos and a Program for Reform, 62 YALE L.J. 515 (1953); Smit, International Aspects of Federal Civil Procedure, 61 Colum. L. REv. 1031 (1961).

41 In the Societe Internationale case, the Swiss government offered a plan designed to achieve maximum compliance with the discovery order. The plan involved the appointment of an independent investigator who would sift the documents in question, and then submit a report to the court identifying the "relevant" documents. Record, 
may seem to provide the best of all possible solutions, it should be kept in mind that these procedures are often expensive, time-consuming and ineffective: "The difficulties surrounding the securing of evidence abroad are such as to confound any general practitioner not experienced in such matters. Even to one who has the necessary experience, the delays and red tape involved in an effort to secure such evidence create a formidable psychological barrier in the prosecution of a litigation." 42 If in spite of delays and red tape the court deems it preferable to resort to one of these alternative procedures, ${ }^{43}$ it should take cognizance of the fact that the procedures will often be ineffective due to the foreign court's refusal to cooperate in furnishing the aid requested in the letters rogatory. ${ }^{44}$ Also, some countries will not permit the taking of depositions on their territory, and others, if they permit the taking of depositions, will not allow specific American procedures such as cross-examination of witnesses or the taking of a full transcript of the hearing. ${ }^{45}$

By applying these determinations to a particular factual situation, a court should be able to resolve which of the competing interests should be given greater weight. In Societe Internationale, ${ }^{46}$ the documents demanded were of vital importance, the Trading with the Enemy Act clearly expressed congressional policy that seized property was only to be returned if the claimant was unconnected with the enemy during the war and the proposed alternative procedures for discovery were deemed unacceptable by the court; however, the potential consequences to the claimant for violating Swiss law were severe indeed. Under the analysis

vol. 5, pp. 1951-55; Brief for Petitioner, pp. 20, 40-42. This plan was not accepted by the district court. 357 U.S. at 203.

42 Heilpern, Procuring Evidence Abroad, 14 TuL. L. REv. 29 (1939). It would seem that these difficulties have not yet diminished: "The existent machinery the American lawyer has at his disposal is expensive, cumbersome and most uncertain." Doyle, Taking Evidence by Deposition and Letters Rogatory and Obtaining Documents in Foreign Territory, ABA, Section of International AND Comparative LAW 37, 49 (1959).

43 See, e.g., Uebersee Finanz-Korporation v. Brownell, 121 F. Supp. 420, 425-26 (D.D.C. 1954) (court ordered issuance of letters rogatory over Alien Property Custodian's objection that the difficulties to be encountered by resort to such procedures would prevent effective discovery).

44 See, e.g., Radio Corp. of America v. Rauland Corp., [1956] 1 Q.B. 618 (English court refused to order oral examination of witnesses and production of documents pursuant to letters rogatory issued by an American court, on the ground that the discovery sought therein was "indirect" rather than "direct" material, and thus unavailable under English law). In a case involving Panama it is doubtful that Panamanian courts would be very cooperative, as their secrecy laws were passed in order to create a haven to attract foreign capital.

45 See generally Doyle, supra note 42 ; Jones, supra note 40, at 519-22; Smit. supra note 40 , at 1058 .

46 See notes 4-8 supra and accompanying text. 
here suggested, the Supreme Court correctly decided that the last was outweighted by the combination of the first three considerations.

In the First Nat'l City Bank case, ${ }^{47}$ the court also reached the desirable conclusion, but for the wrong reason. There is a strong national policy against tax evasion, the documents subpoenaed were essential to establish a case against a delinquent taxpayer and the potential consequences of violating the law there involved were relatively insignificant. Unless the Bank had proposed an alternative procedure which would have achieved effective production of the documents, the subpoena should have issued whether or not foreign law was adequately proved.

In Ings v. Ferguson ${ }^{48}$ there was no reason to vacate the subpoena merely because compliance might have resulted in the violation of foreign law unless it were shown that employment of alternative procedures would achieve substantially the results that would be achieved by issuance of a subpoena. However, if in this situation it wexe proved that compliance with the subpoena would definitely result in a violation of Canadian law, perhaps resort to alternative procedures would be more justifiable than in First Nat'l City Bank, since the documents requested in Ings could well be less essential to carrying out the policies underlying the Bankruptcy Act, than were the documents in First Nat'l City Bank to fulfillment of the purpose of the Internal Revenue Code.

In light of this analysis, therefore, it is clear that the court in the Chase Manhattan Bank case ${ }^{49}$ was only justified in vacating the subpoena if it were shown that alternative procedures would be equally effective in obtaining the requested information, or, if due to the nature of the grand jury investigation, the documents were not necessary to the conduct of the investigation and the policy considerations were not substantial.

The essential nature of a test based on these determinations is not greatly dissimilar from those recently utilized in solving problems of domestic conflict of laws, where some courts have turned from the results demanded by strict application of territorial concepts, to a test based on a balancing of conflicting interests. ${ }^{50}$ It should be noted, however, that

47 First Nat'l City Bank v. Internal Revenue Service, 271 F.2d 616 (2d Cir. 1959).

48282 F.2d 149 (2d Cir. 1960).

40 Application of The Chase Manhattan Bank, 297 F.2d 611 (2d Cir. 1962).

50 These have been cases raising constitutional issues, see Pacific Employers Ins. Co. v. Industrial Acc. Comm'n, 306 U.S. 493 (1939); Alaska Packers Ass'n v. Industrial Acc. Comm'n, 294 U.S. 532 (1935). Cf. Pearson v. Northeast Airlines, Inc., 309 F.2d 553 (2d Cir. 1962), cert. denied, 372 U.S. 912 (1963), adopting en banc, opinion of Kaufman, J., dissenting, in Pearson v. Northeast Airlines, Inc., 307 F.2d 131, 136 (2d Cir. 1962); Currie, The Constitution and The Choice of Law: Governmental Interests and the Judicial Function, 26 U. CHI. L. REv. 9 (1958). Cases presenting ordinary conflicts problems are often still resolved by traditional Restatement rules. 
the domestic "balancing of interests" test is not entirely viable in an international context. The problem here presented is one of the few exceptional cases where the positive commands of two sovereigns are in absolute conflict. Here, the forum state is never disinterested. Furthermore, whereas the unifying effect of the full faith and credit clause makes possible the resolution of domestic conflicts "by appraising the governmental interests of each jurisdiction and turning the scale of decision according to their weight," 51 a determination of the national interests of each foreign state whose laws are involved in litigation, is not a function of the courts, but the responsibility of the executive branch. ${ }^{52}$ In view of the possible consequences to the foreign relations of the United States resulting from a court's ordering the production of documents from a jurisdiction in violation of the laws of that jurisdiction, the executive branch should be consulted by the court, not only as to the interests of the United States in the litigation, but also as to what may constitute the interests of the foreign government whose laws are involved.53 One court, indicating that the foreign policy implications of its decision would not deter it from proceeding, stated very clearly, and it is submitted, properly, that

If necessary, the Court will not hesitate in future proceedings to seek advice and clarification of the Government's position by calling in government officials capable of advising the court. It must be remembered that the responsibility of the Court is to

51 Alaska Packers Ass'n v. Industrial Acc. Comm'n, 294 U.S. 532, 547 (1935).

62 See, e.g., Chicago \& Southern Air Lines v. Waterman Corp., 333 U.S. 103, 111 (1948): "[T] he very nature of executive decisions as to foreign policy is political, not judicial. Such decisions are wholly confided by our Constitution to the political departments of the government, Executive and Legislative. They are delicate, complex, and involve large elements of prophecy. They are and should be undertaken only by those directly responsible to the people whose welfare they advance or imperil. They are decisions of a kind for which the Judiciary has neither aptitude, facilities nor responsibility and which has long been held to belong in the domain of political power not subject to judicial intrusion or inquiry." Cf. Oetjen v. Central Leather Co., 246 U.S. 297, 304 (1918): "To permit the validity of the acts of one sovereign State to be reëxamined and perhaps condemned by the courts of another would very certainly 'imperil the amicable relations between governments and vex the peace of nations.'" The proposition advanced in this comment would not involve an examination by American courts of the validity of an act of a foreign state, see Banco Nacional de Cuba v. Sabbatino, 376 U.S. 398 (1964), but would instead, accepting the validity of that law, balance the interest in complying with it, against the interest in obtaining the documents.

58 Any department of the executive branch may bring to the attention of the court that department's views and policies by requesting the Attomey General to file a Suggestion of Interest pursuant to 16 Stat. 162 (1870), 5 U.S.C. \& 316 (1958). See, e.g., Clark v. Allen, 331 U.S. 503, 513 (1947); International Products Corp. v. Koons, 325 F.2d 403, 408 (2d Cir. 1963). See also Bilder, The Office of the Legal Advisor, 56 AM. J. INT'L L. 633, 676-77 (1962). 
protect not only those appearing then, but also to protect the American public who have a vital interest in all proceedings. ${ }^{54}$

Undoubtedly situations may arise where the court's order is met by a strong negative reaction abroad. This reaction may even take the form of foreign legislative, ${ }^{55}$ judicial ${ }^{56}$ or executive ${ }^{57}$ action. However, the assessment of such a possibility is no more the proper function of the court than is the determination of a foreign government's interests. Once again, this matter is within the province of the executive branch from which the court can receive advice. Furthermore, even after such a court order had been issued, were a strong foreign reaction to ensue, the executive branch could advise the court as to whether in its opinion national policy objectives would be better served by vacating or by leaving the order in force. It must be emphasized, however, that the question of whether or not to issue the production order is a judicial one. The advice of the executive is only solicited in order to aid the court in arriving at its decision. Thus, if the consultation machinery breaks down or if the executive prefers to remain uncommitted on an issue, ${ }^{58}$ the court still has the responsibility of balancing the competing policy considerations and reaching a decision. 59

54 In re Investigation of World Arrangements with Relation to the Production, Transportation, Refining \& Distribution of Petroleum, 13 F.R.D. 280, 283 (D.D.C. 1952).

55 When subpoenas were served on Canadians and Canadian corporations engaged in the newsprint industry, to appear and produce documents before an American grand jury, great public indignation was aroused in Canada; the legislature of Ontario went so far as to pass a special statute prohibiting the removal of documents from Ontario in compliance with an order of a foreign judicial, legislative or administrative authority. A violation of this statute is punishable by up to one year's imprisonment. The Business Records Protection Act, Ontario Rev. Stat. ch. 44 (1950).

56 In United States v. Imperial Chem. Indus., Ltd., 105 F. Supp. 215 (S.D.N.Y. 1952), an antitrust suit brought against Du Pont, ICI and other nylon manufacturers, the district court ordered ICI to license certain patents to all parties desiring them. British Nylon Spinners, Ltd., the exclusive licensee of those patents in England, successfully brought suit in England to enjoin breach of the contract granting it the exclusive rights to the patents. British Nylon Spinners, Ltd., v. Imperial Chem. Indus., Ltd., [1952] 2 All E.R. 780 (C.A.). No further action was taken in the United States against ICI for failure to comply with that part of the district court order.

57 See In re Investigation of World Arrangements with Relation to the Production, Transportation, Refining \& Distribution of Petroleum, 13 F.R.D. 280 (D.D.C. 1952). There, Anglo-Iranian Oil Co., Ltd. was served with a subpoena duces tecum to produce documents before an American grand jury. The Minister of Fuel and Power of Great Britain ordered the company not to produce any documents which were not located in the United States. Id. at 289. Note also the "constructive confiscation" of accounts in Societe Internationale; see text accompanying notes 4-5 supra.

58 See, e.g., Record p. 402, Societe Internationale v. Rogers, 357 U.S. 197 (1958).

50 "Despite the broad statement in Oetjen that "The conduct of the foreign relations of our Government is committed by the Constitution to the Executive and 
The great latitude that a court has in its power to apply sanctions for noncompliance with a subpoena or a discovery order, is of course vital to the effectiveness of its directives. The mere threat that sanctions within the power of the court to apply shall be utilized will generally intimidate a party into maximizing its efforts to comply. If the result is compliance, the inquiry need be carried no further, as the objective of obtaining the "fullest possible knowledge of the issues and facts before trial,"60 will have been attained. It is only after the fact of a party's noncompliance that a court need determine whether in that particular situation a certain sanction may constitutionally be imposed, and further, whether the imposition of that sanction would be desirable. This is a determination which a court cannot make at the time of issuance of the order to produce since at that time all the facts relevant to sanctioning will not yet be before the court. Imposition of a sanction must be justified on either a remedial or a punitive rationale and the sanction imposed must be tailored to the purposes of these alternatives. If the reason for the party's noncompliance is impossibility, it would be senseless to apply sanctions as neither rationale is applicable. A party should not be punished for something that is not his fault; thus, if good faith efforts at compliance are made, a punitive sanction would be indefensible. While, if the action required of him turns out to be impossible, no sanction would alter his good faith inability to comply; thus, sanctioning could in no sense be remedial. ${ }^{61}$ Therefore, it can readily be seen that it is only when all the facts are present that a court can decide whether or not remedial sanctions might bring about compliance and whether punitive sanctioning would be justifiable. By thus delaying the decision as to sanctions, courts can utilize their sanctioning power most effectively, while at the same time being ensured of maximum efforts at compliance on the part of the party ordered to produce. ${ }^{62}$

If compliance is not achieved, a court has available, in a proper case, a whole spectrum of remedies. Its power to apply some of these sanctions is, however, subject to constitutional limitations. The following short discussion of these remedies shall be restricted to those available to the

Legislative . . Departments,' . . . it cannot of course be thought that 'every case or controversy which touches foreign relations lies beyond judicial cognizance.' Banco Nacional de Cuba v. Sabbatino, 376 U.S. 398, 423 (1964).

60 Hickman v. Taylor, 329 U.S. 495, 501 (1947).

61 The "remedial" sentence is considered a civil punishment, even though it includes fines and "coercive imprisonment."

62 See, e.g., In re Reicher, 159 F. Supp. 161 (S.D.N.Y. 1958) (IRS summons-question of whether petitioner was excused from producing records was best determined in a later contempt proceeding). 
federal courts, as few state courts are confronted with the issues which are the subject of this comment. ${ }^{63}$

In the case of a party's refusal to answer questions or allow discovery, the Federal Rules of Civil Procedure authorize the court to make such orders "as are just," among others, to enter orders establishing facts or excluding evidence or striking pleadings, or authorizing judgments of dismissal or default. ${ }^{64}$ The court's power to apply these sanctions is not, however, absolute. ${ }^{65}$ Especially the availability of default or dismissal must be determined in light of the due process limitation enunciated in Societe Internationale:

[W] think that Rule 37 should not be construed to authorize dismisal of this complaint because of petitioner's noncompliance with a pretrial production order when it has been established that failure to comply has been due to inability, and not to willfulness, bad faith, or any fault of petitioner.66

The rule here set down applies at least to default judgments in the case of a defendant, and to dismissals in the case of a "quasi-defendant" or a defendant cast in the role of a plaintiff. 67 The rule should probably also apply to dismissal in the case of a plaintiff having none of the characteristics of a defendant. ${ }^{68}$

03 Only one state case has been found which involved the production of documents located at a situs the law of which prohibited their removal or the disclosure of their contents. Hirshhorn v. Hirshhorn, 278 App. Div. 1006, 105 N.Y.S.2d 628 (1951).

64 FED. R. Civ. P. 37(b).

65 The Notes of the Advisory Committee on Rules, 28 U.S.C. at 4325 (1952) state: "The provisions of this rule [rule 37] authorizing orders establishing facts or excluding evidence or striking pleadings, or authorizing judgments of dismissal or default, for refusal to answer questions or permit inspection or otherwise make discovery, are in accord with Hammond Packing Co. v. Arkansas, 212 U.S. 322 . . . (1909), which distinguishes between the justifiable use of such measures as a means of compelling the production of evidence, and their unjustifiable use, as in Hovey v. Elliot, 167 U.S. 409 . . (1897), for the mere purpose of punishing for contempt."

66 Societe Internationale v. Rogers, 357 U.S. 197, 212 (1958). (Emphasis added.) In this decision the court laid to rest any axtificial distinctions based on the alternative use of refusal and failure to comply in Rule 37. Id. at 207-08. By the accepted meaning of the word, Interhandel clearly refused to comply with the production order for fear of prosecution under Swiss law, yet the Court labeled the noncompliance a "failure to comply." Id. at 212.

67 $I d$. at 210.

68 A superficial analysis would seem to dictate the opposite, due to the argument that in invoking the aid of the court a plaintiff seeking to alter the status quo submits itself to all the orders the court might issue, and that if after such submission a plaintiff disobeys an order, dismissal is warranted. The argument states a conclusion, as the issue here is the propriety of the court's order of dismissal. A plaintiff who has established a prima facie case would surely not be required to submit to any judicial order. The question therefore is whether the rationale for dismissal for failure to 
The "constructive seizure" of the documents by Swiss authorities in Societe Internationale established "inability" to comply with the discovery order insofar as the sanction of dismissal was concerned. However, the concept of "inability" is in this context a shifting one. Although in Societe Internationale, Interhandel had shown the requisite "inability" to avoid the sanction of dismissal, it was still subject to the lesser sanctions provided by rule 37- "It may be that in the absence of complete disclosure by petitioner, the District Court would be justified in drawing inferences unfavorable to petitioner as to particular events." 69 Thus noncompliance with a discovery order can result in some sanctions, even if bona fide efforts to comply had been made; and even these lesser sanctions may well destroy a litigant's chances of success.

Inexcusable noncompliance with a subpoena is a violation of a citizen's positive duty to act as a witness, or to produce evidence when called upon to do so.70 The power to punish such a violation stems from the court's inherent power to punish contempt, ${ }^{71}$ thus the choice of which sanction to apply, and when, is almost totally at the discretion of the court. However, noncompliance with a subpoena which in all other respects is valid, is still excused if inability is established:

Ordinarily, one charged for contempt of court for failure to

comply with a discovery order is logically any more applicable to a plaintiff who has established a prima facie case, than to a defendant, when neither has acted wilfully or in bad faith. The language of the Supreme Court does not indicate that any such distinction will be made, id. at 210 , and it is submitted that dismissal here is equally unwarranted in the case of a plaintiff as is a default judgment in the case of a defendant.

69 Societe Internationale v. Rogers, 357 U.S. 197, 213 (1958). Later cases have not adequately explored the question of what constitutes the requisite "inability" to preclude a court from entering a judgment of default or dismissal upon noncompliance with a discovery order. See Read v. Ulmer, 308 F.2d 915, 918 (5th Cir. 1962); Syracuse Broadcasting Corp. v. Newhouse, 271 F.2d 910, 914 (2d Cir. 1959); Independent Prods. Corp. v. Loew's, Inc., 30 F.R.D. 377 (S.D.N.Y. 1962); Bernat v. Pennsylvania Ry., 14 F.R.D. 465 (E.D. Pa. 1953).

If for purposes of dismissal or default judgment, "constructive seizure" of documents established the requisite inability, perhaps authoritative statements by foreign officials that action would be taken against a party if that party violates the foreign law, would also be sufficient to prevent the entering of a judgment of default or dismissal. Perhaps evidence that in past cases when a party had violated the law in question, foreign officials had acted would also be sufficient. It must, of course, be clearly established that the party had made bona fide efforts to comply; but even then, a mere showing of the foreign law, without some affirmative action on the part of foreign authorities would not seem to show the inability needed to preclude a judgment of default or dismissal against the noncomplying party. See also Rosenberg, Sanctions to Effectuate Pretrial Discovery, 58 ColvM. L. Rev. 480 (1958); Note, 46 CAIIF. L. Rev. 836 (1958).

70 United States v. Bryan, 339 U.S. 323, 391 (1950).

71 Gompers v. Buck's Stove \& Range Co., 221 U.S. 418, 450 (1911). 
comply with a court order makes a complete defense by proving that he is unable to comply. A court will not imprison a witness for failure to produce documents which he does not have unless he is responsible for their unavailability ... or is impeding justice by not explaining what happened to them $\ldots .^{2}$

The inability referred to here, however, is an actual physical inability to comply, and would not seem to encompass the "inability" established in Societe Internationale. Thus, although good faith efforts to comply with the subpoena must be made if noncompliance is to be excused,73 no case has been found which has held that noncompliance must be excused if bona fide efforts were made to comply with the subpoena. ${ }^{74}$

The argument has been advanced that the eighth amendment prohibition against cruel and unusual punishments ${ }^{75}$ constitutes a limitation on a court's power to punish for contempt. ${ }^{76}$ As a general proposition this would seem to be of doubtful validity, as the cruel and unusual punishment clause has been very infrequently applied, is generally thought to be a prohibition merely against torture and other barbaric measures and is arguably only applicable to criminal as opposed to civil remedies. ${ }^{77}$ However, the possible existence of this constitutional limitation should be kept in mind by the courts, especially in applying punitive as opposed to remedial sanctions. By careful application of sanctions, especially by skillful use of remedial punishment, the courts should be able to obtain substantial compliance with subpoenas and discovery orders, even in those cases where the mere threat of sanctions did not suffice to achieve the production of the desired documents.

With the spread of government regulation over an ever-increasing group of activities, and with the expansion of international commercial and cultural ties, the courts must abandon a rule based on territoriality,

72 United States v. Bryan, 339 U.S. 323, 330-31 (1950). (Emphasis added.)

73 United States v. Fleishman, 339 U.S. 349 (1950); United States v. Bryan, 339 U.S. 323, 332 (1950). See also Lopiparo v. United States, 216 F.2d 87 (8th Cir. 1954).

74 For a general survey of the power to punish contempt, see GoldFars, The CoNTEMPT POWER (1963).

75 U.S. ConsT. amend VIII.

76 The argument stems from the decision in Robinson $v$. California, 370 U.S. 660 (1962), in which the Supreme Court struck down a California statute imposing a prison sentence for the "crime" of narcotics addiction. In holding the statute invalid under the eighth amendment, the Court stated: "To be sure, imprisonment for ninety days is not, in the abstract, a punishment which is either cruel or unusual. But the question cannot be considered in the abstract. Even one day in prison would be a cruel and unusual punishment for the "crime" of having a common cold." Id. at 667. This proposition is advanced in Note, Limitations on the Federal Judicial Power to Compel Acts Violating Foreign Law, 63 Colum. L. REv. 1441, 1472-73 (1963).

77 See discussion in Goldfarb, The Contempt Power 264-73 (1963). 
which, although adequate in its time, is no longer suited to the exigencies of the modern world. ${ }^{78}$ The adoption of the proposed approach to this problem would not only assist governmental agencies to fulfill their roles, but would aid the attainment of national objectives and facilitate litigation. At the same time, judicious application of the proposed rules should not in the least disrupt the foreign relations of the United States, nor in any way violate accepted principles of constitutional or international law.

78 A similar problem of extraterritorial application of court orders arises under the antitrust and patent and trademark infringement laws of the United States. It often occurs that compliance with a judgment in an antitrust or infringement action would require the defendant to incur liability both under foreign contract law and under foreign regulatory and penal statutes. The actions taken by American courts faced with these problems have also not been consistent. See, e.g., Vanity Fair Mills, Inc. v. T. Eaton Co., 234 F.2d 633 (2d Cir. 1956), modifying, 133 F. Supp. 522 (S.D.N.Y. 1955), cert. denied, 352 U.S. 871 (1956), United States v. Watchmakers of Switzerland Information Center, Inc., 5 TrADE REg. REP. (1963 Trade Gas). I 70600 (S.D.N.Y. Dec. 20, 1962); United States v. Holophane Co., 119 F. Supp. 114 (S.D. Ohio 1954), aff'd per curiam, 352 U.S. 903 (1956); United States v. Imperial Chem. Indus., Ltd., 105 F. Supp. 215 (S.D.N.Y. 1952), supplementing, 100 F. Supp. 504 (S.D.N.Y. 1951); United States v. Timken Roller Bearing Co., 83 F. Supp. 284 (N.D. Ohio 1949), modified, 341 U.S. 593 (1951); United States v. National Lead Co., 63 F. Supp. 513 (S.D.N.Y. 1945), aff'd, 332 U.S. 319 (1947). See Note, Limitations on the Federal Judicial Power to Compel Acts Violating Foreign Law, 63 Colum. L. REv. 1441 (1963). For related questions, see United States v. First Nat'l City Bank, 321 F.2d 14 (2d Gir. 1963), aff'd en banc, 325 F.2d 1020 (2d Cir. 1964); United States v. Ross, 302 F.2d 831 (2d Cir. 1962). 